\title{
Article
}

\section{MIP-based electrochemical protein profiling}

Bueno, Lígia, El-Sharif, Hazim F., Salles, Maiara O., Boehm, Ryan D., Narayan, Roger J., Paixão, Thiago R.L.C. and Reddy, Subrayal M

Available at http://clok.uclan.ac.uk/13789/

Bueno, Lígia, El-Sharif, Hazim F., Salles, Maiara O., Boehm, Ryan D., Narayan, Roger J., Paixão, Thiago R.L.C. and Reddy, Subrayal M ORCID: 0000-00027362-184X (2014) MIP-based electrochemical protein profiling. Sensors and Actuators B: Chemical, 204 . pp. 88-95. ISSN 0925-4005

It is advisable to refer to the publisher's version if you intend to cite from the work. http://dx.doi.org/10.1016/j.snb.2014.07.100

For more information about UCLan's research in this area go to http://www.uclan.ac.uk/researchgroups/ and search for <name of research Group>.

For information about Research generally at UCLan please go to http://www.uclan.ac.uk/research/

All outputs in CLoK are protected by Intellectual Property Rights law, including Copyright law. Copyright, IPR and Moral Rights for the works on this site are retained by the individual authors and/or other copyright owners. Terms and conditions for use of this material are defined in the policies page.

\section{CLoK}

Central Lancashire online Knowledge www.clok.uclan.ac.uk

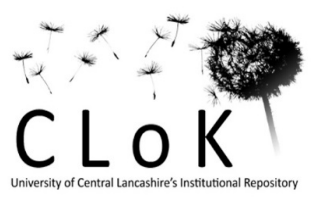


2

3 Lígia Bueno $\#^{(1)}$, Hazim F. El-Sharif $\#^{(2)}$, Maiara O. Salles $\#^{(1)}$, Ryan D. Boehm ${ }^{(3)}$,

4 Roger J. Narayan ${ }^{(3)}$, Thiago R. L. C. Paixão ${ }^{(1)}$ and Subrayal M. Reddy ${ }^{\left(2^{*}\right)}$

5

$6{ }^{1}$ Instituto de Quimica, Universidade de São Paulo, Avenida Professor Lineu Prestes, $7 \quad 748$ - São Paulo - SP, Brasil.

$8 \quad{ }^{2}$ Department of Chemistry, FEPS, University of Surrey, Guildford, UK, GU2 7XH.

$9{ }^{3}$ Joint Departments of Biomedical Engineering, University of North Carolina,

10 Raleigh, USA.

11

12 \# These authors contributed equally to this work (co-first authorship)

13

14 *Corresponding Author: Tel: +44 (0) 1483686396, s.reddy@ surrey.ac.uk 


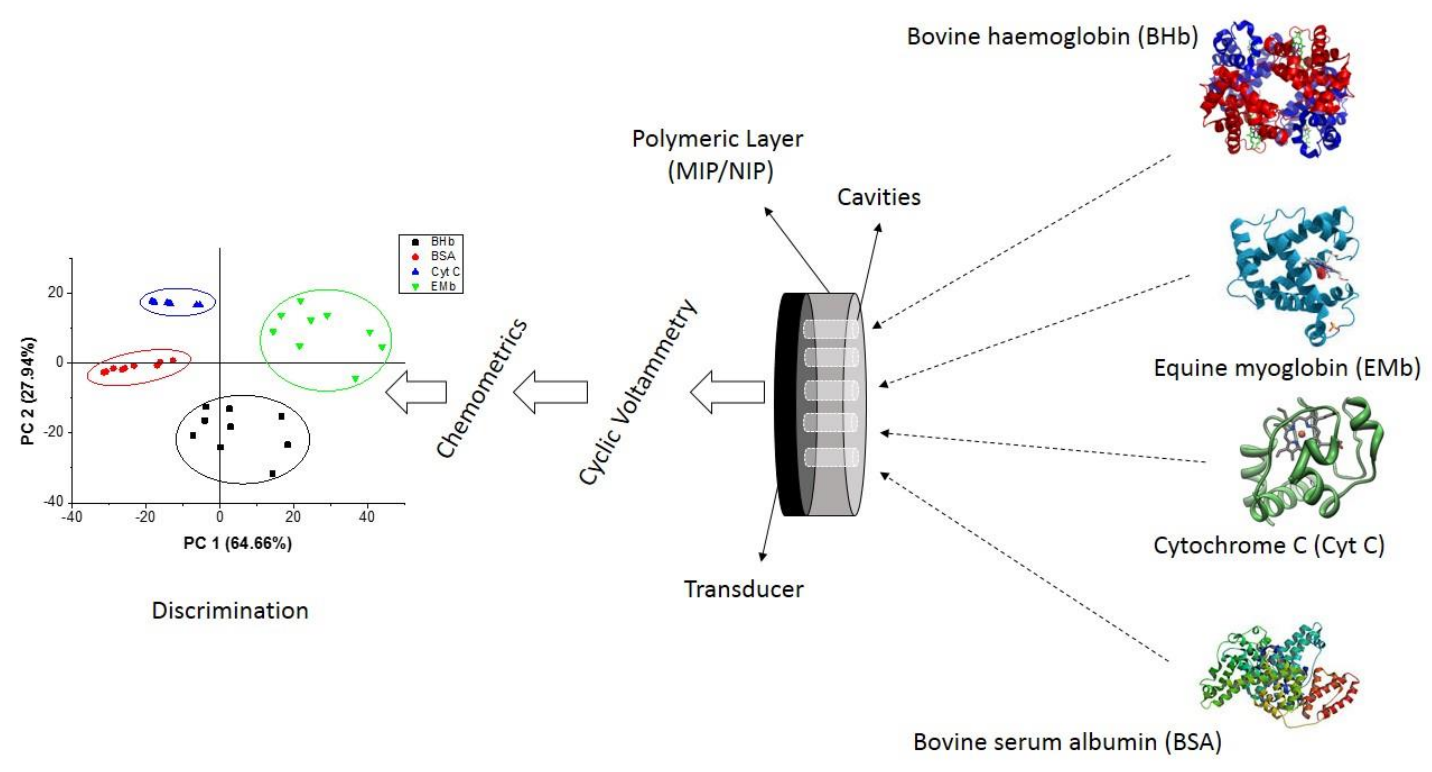

16

17 Highlights

18 - Electrochemical MIP-based biosensor fabricated for rapid protein detection.

19 - We report the coupling of electrochemical and pattern recognition techniques.

20 - Selective synthetic MIP recognition of a range of bio-significant proteins.

21 - Protein fingerprint profiling by principal component analysis

22

- Faster detection rates at lower concentrations. 


\section{Abstract}

We present the development of an electrochemical biosensor based on modified glassy carbon (GC) electrodes using hydrogel-based molecularly imprinted polymers (MIPs) has been fabricated for protein detection. The coupling of pattern recognition techniques via principal component analysis (PCA) has resulted in unique protein fingerprints for corresponding protein templates, allowing for MIP-based protein profiling. Polyacrylamide MIPs for memory imprinting of bovine haemoglobin (BHb), equine myoglobin (EMb), cytochrome $\mathrm{C}(\mathrm{Cyt} \mathrm{C})$, and bovine serum albumin (BSA), alongside a non-imprinted polymer (NIP) control, were spectrophotometrically, and electrochemically characterised using modified GC electrodes. Rebinding capacities $(\mathrm{Q})$ were revealed to be higher for larger proteins $(\mathrm{BHb}$ and $\mathrm{BSA}, \mathrm{Q} \approx 4.5)$ while $(\mathrm{EMb}$ and $\mathrm{Cyt} \mathrm{C}, \mathrm{Q} \approx 2.5)$. Electrochemical results show that due to the selective nature of MIPs, protein arrival at the electrode via diffusion is delayed, in comparison to a NIP, by attractive selective interactions with exposed MIP cavities. However, at lower concentrations such discriminations are difficult due to low levels of MIP rebinding. PCA loading plots revealed 5 variables

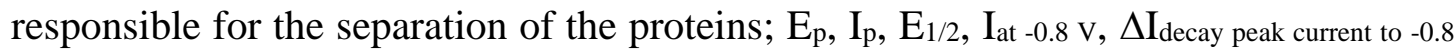
v. Statistical symmetric measures of agreement using Cohen's kappa coefficient $(\kappa)$ were revealed to be $63 \%$ for bare GC, $96 \%$ for NIP and $100 \%$ for MIP. Therefore, our results show that with the use of PCA such discriminations are achievable, also with the advantage of faster detection rates. The possibilities for this MIP technology once fully developed are vast, including uses in bio-sample clean-up or selective extraction, replacement of biological antibodies in immunoassays, as well as biosensors for medicine, food and the environment. 
50 Biosensors; Electrochemical protein detection; Molecularly imprinted polymers;

51 Pattern recognition; Modified electrodes; Electronic tongue.

\section{Introduction}

Molecularly imprinted polymers (MIPs) are rapidly becoming viable alternatives to natural antibodies for sensor technology [1-4]. MIPs offer many advantages in terms of shelf-life, stability, robustness, cost, and ease of preparation [5]. While biological antibodies are routinely used in diagnostic tests and are able to give precise results, they are notably unstable and require lengthy procedures to grow,

59 isolate, and treat before they can be used; ethical issues surrounding the use of animalbased antibodies are also a common drawback [6].

Over the years molecular imprinting has become an effective method for imprinting highly specific and selective recognition sites in synthetic polymers $[7,8]$. As such, MIPs have been regarded as 'antibody mimics' and have shown clear advantages over actual antibodies for sensor technology as they are highly crosslinked, intrinsically stable, robust, and have potential use in extreme environments [9]. However, in the imprinting community, bio-macromolecules such as proteins present a variety of challenges and successful imprints are highly sought after. Proteins are relatively labile and have changeable conformations that are sensitive to various

69 factors (e.g., solvent environments, $\mathrm{pH}$ and temperature) [7,10-12]. Moreover, a large number of proteins are vital markers; for example, in the case of haemoglobin,

71 mutations in genes that encode for the protein's subunits can result in hereditary 72 diseases such as sickle cell anaemia, thalassaemia, and haemoglobinopathies [1]. 73 However, protein-detecting arrays remain under-developed due to the lack of highly 
74 selective and specific binding agents that interact with protein surfaces through 75 complementary interactions [13]. It is therefore imperative to develop new 76 methodologies based on protein detection for applications in proteomics, medical 77 diagnostics, and even pathogen detection [13].

Differential receptor arrays, that in nature routinely conduct pattern-based 79 recognition, have already been artificially constructed using synthetic receptors/transducers and could provide a possible solution. Such devices have been

81 labelled as electronic noses for smell recognition and electronic tongues for taste 82 recognition. These synthetic receptors/transducers or sensors have low selectivity and 83 consequently exhibit over-lapping signals for different species, providing a fingerprint 84 of a sample that could be used for qualitative discrimination [14]. The operation of 85 these electronic devices uses a concept of the human tongue and nose known as global 86 selectivity [15], in which the biological system does not identify a particular substance 87 but brings together all of the extracted information into patterns that the brain 88 decodes. An electronic sensor that works in a similar way is a chememotric tool e.g., 89 principal component analysis (PCA). These tools decode complex information and 90 classify standards for recognition [16-18]. Takeuchi et al. previously applied the 91 electronic tongue strategy to the molecular recognition of proteins by using imprinted 92 acrylic acid (AA) and 2-dimethylaminoethyl methacrylate (DMA) polymers [19,20]. 93 Three-dimensional PCA scores of the binding data described by Takeuchi et al. 94 revealed that a clear protein distinction was possible and that protein-imprinted 95 polymer arrays can be applied to protein profiling by pattern analysis of binding 96 activity for each polymer [19-21]. PCA has also been used in conjunction with 97 electrochemical methods such as cyclic voltammetry [16,17,22-25]. An attractive 


\section{Materials and methods}

121 the years to come $[8,29]$.

\subsection{Materials}

approach for the development of biochemical sensors would be the integration of smart materials (e.g., MIPs) with said electrochemical techniques

This paper demonstrates the use of pattern recognition techniques to uniquely identify fingerprint profiles for four different proteins by coupling electrochemical sensor strategies with hydrogel-based MIPs. The four proteins chosen were on the basis of their different biological roles, sizes, and electrochemical activities. Bovine hemoglobin (BHb, $64.5 \mathrm{kda})$ well known for its function in the vascular system as a carrier of oxygen, also in aiding the transport of carbon dioxide and regulating blood $\mathrm{pH}$ [26]. Both $\mathrm{BHb}$ and $\mathrm{EMb}(17.5 \mathrm{kda})$ exhibit well-known electrochemical behaviour [1,24,27,28]. Cytochrome complex (Cyt C, $12.5 \mathrm{kda}$ ) is an essential component of the electron transport chain but exhibits a lack of oxygen binding, despite being an iron-containing metalloprotein that is capable of undergoing oxidation and reduction. Bovine serum albumin (BSA, MW $66.0 \mathrm{kDa}$ ) is a nonmetalloprotein with similar molecular weight to $\mathrm{BHb}$, and serves to test the selectivity of the BHb-MIP to BSA compared to template $\mathrm{BHb}$.

Our results demonstrate sensitivity and selectivity; if such devices can be further optimised for MIP parameters, then perhaps these MIP-based strategies can offer viable methods for the characterisation of proteins. With the aid of inexpensive synthetic smart material hydrogel MIPs, new biosensor platforms for rapid screening, diagnosis, and monitoring of a variety of disorders can be readily developed within 
Acrylamide (AA), N,N-methylenebisacrylamide (bis-AA), ammonium

123

125

126

127

128

130

131

132

133 persulphate (APS), N,N,N,N-tetramethylethyldiamine (TEMED), sodium dodecylsulphate (SDS), glacial acetic acid $(\mathrm{AcOH})$, phosphate buffered saline (PBS) tablets $\left(137 \mathrm{mmol} \mathrm{L}{ }^{-1} \mathrm{NaCl} ; 27 \mathrm{mmol} \mathrm{L}{ }^{-1} \mathrm{KCl} ; 10 \mathrm{mmol} \mathrm{L}^{-1} \mathrm{Na}_{2} \mathrm{HPO}_{4} ; 1.76 \mathrm{mmol} \mathrm{L}^{-1}\right.$ $\mathrm{KH}_{2} \mathrm{PO}_{4}$ ), methyl viologen, bovine haemoglobin $(\mathrm{BHb})$, bovine serum albumin (BSA), cytochrome $\mathrm{C}(\mathrm{Cyt} \mathrm{C})$, and equine heart myoglobin (EMb) were all purchased from Sigma-Aldrich (Poole, UK). Sieves $(75 \mu \mathrm{m})$ were purchased from Inoxia Ltd. (Guildford, UK). Polycarbonate membranes $25 \mathrm{~mm}$ in diameter, $0.8 \mu \mathrm{m}$ pore size were purchased from Osmonic Inc., Minnetonka, USA.

\subsection{Hydrogel production}

Hydrogel MIPs for BHb, EMb, Cyt C and BSA were synthesised by separately dissolving AA (54 mg) and bis-AA as cross-linker $(6 \mathrm{mg})$ along with template protein (12 mg) in $960 \mu \mathrm{L}$ of MilliQ water. The solutions were purged with nitrogen for 5 minutes, followed by an addition of $20 \mu \mathrm{L}$ of a $10 \%$ (w/v) APS solution and $20 \mu \mathrm{L}$ of a $5 \%(\mathrm{v} / \mathrm{v})$ TEMED solution. Polymerisation occurred at room temperature $\left(\sim 22 \mathrm{C}^{0}\right)$, giving final total gel densities $(\% \mathrm{~T})$ of $6 \% \mathrm{~T}, \mathrm{AA} / \mathrm{bis}-\mathrm{AA}(\mathrm{w} / \mathrm{v})$ and crosslinking densities $(\% \mathrm{C})$ of $10 \% \mathrm{C}(9: 1, \mathrm{w} / \mathrm{w})$. For every MIP created, a control non-imprinted polymer (NIP) was prepared in an identical manner but in the absence of protein.

\subsection{Hydrogel conditioning}

After polymerization, the gels were granulated separately using a $75 \mu \mathrm{m}$ sieve.

Of the resulting gels, $500 \mathrm{mg}$ were conditioned by washing with five $1 \mathrm{~mL}$ volumes of $150 \mathrm{mmol} \mathrm{L}^{-1}$ PBS buffer ( $\mathrm{pH}$ 7.4). This was followed by five $1 \mathrm{~mL}$ volumes of a $10 \%(\mathrm{w} / \mathrm{v}): 10 \%(\mathrm{v} / \mathrm{v}) \mathrm{SDS}: \mathrm{AcOH}(\mathrm{pH} 2.8)$. A further five $1 \mathrm{~mL}$ washes of $150 \mathrm{mmol}$ 
$\mathrm{L}^{-1}$ PBS buffer ( $\mathrm{pH}$ 7.4) were conducted to remove any residual SDS:AcOH eluent

148 and equilibrate the gels. Each conditioning step was followed by a centrifugation

149 using an Eppendorf mini-spin plus centrifuge (Fisher Scientific, Loughborough, UK)

150 for 3 minutes at $6000 \mathrm{rpm}$ (RCF: $2419 \mathrm{x} \mathrm{g}$ ). All supernatants were collected for

151 analysis by spectrophotometry to verify the extent of template removal. It should be

152 noted that the last water wash and SDS:AcOH eluent fractions were not observed to

153 contain any protein. Therefore we are confident that any remaining template protein

154 within the MIPs did not continue to leach out during future studies.

\subsection{Hydrogel characterization}

The rebinding efficiency of the MIPs and NIPs produced were characterized using a UV mini-1240 CE spectrophotometer (Shimadzu Europa, Milton Keynes, UK). After elution washing of the polymers MIP and NIP (500 mg) were treated with $3 \mathrm{mg} / \mathrm{ml}$ of protein in an eppendorf and polymer/protein solution mixed on a rotary

161 vortex mixer for 5 minutes followed by centrifugation. The supernatant was removed

162 and protein concentration measured spectrophotometrically (at $404 \mathrm{~nm}$ for $\mathrm{BHb} ; 280$

$163 \mathrm{~nm}$ for BSA, $408 \mathrm{~nm}$ for Mb and $402 \mathrm{~nm}$ for Cyt C). Protein loaded MIPs and NIPs

164 were then washed with five sequential washes of water $(1 \mathrm{ml}$ each) and the washes

165 combined. Again the absorbance of the washes was also taken. All protein 166 unaccounted for at this stage was deemed to be selectively bound to the MIP or NIP

167 and determined by subtraction of the protein levels in supernatants (after loading and 168 water washing) from the initial load. Optical microscope images of granulated and 169 washed MIPs and NIPs were also taken.

\section{$171 \quad 2.5$ Electrochemical analysis}


173 with a $20 \mathrm{mg}$ conditioned hydrogel layer of each: NIP, BHb MIP, Cyt C MIP, BSA

174 MIP, and EMb MIP. The layer was kept in place by a polycarbonate membrane $(0.8$

$175 \mu \mathrm{m})$ placed over the modified electrode surface and held down with the aid of a

176 rubber ring. The polycarbonate membrane was chosen because its pores are small

177 enough to retain the gel $(75 \mu \mathrm{m}$ particle size $)$ and, at the same time, large enough to

178 allow protein in solution to diffuse through. The potential range used in all

179 electrochemical measurements was 0.0 to $-0.9 \mathrm{~V}$ with a scan rate of $100 \mathrm{mV} \mathrm{s}{ }^{-1}$; a

$180 \mathrm{Ag} / \mathrm{AgCl}$ reference electrode (saturated $\mathrm{KCl}$ ) and platinum counter electrode

181 connected to an Autolab II potentiostat/galvanostat were used in this study (Utrecht,

182 Netherlands). The modified electrodes were first placed in a solution of PBS (pH 7.4)

183 and SDS 5\% (w/v) and analysed after a $20 \mathrm{~min}$ period of equilibration. Subsequently,

$18415.4 \mu \mathrm{mol} \mathrm{L} \mathrm{L}^{-1}$ protein solutions (BHb, BSA, EMb and Cyt C) dissolved in PBS buffer $185(\mathrm{pH}$ 7.4) and SDS 5\% (w/v) were placed independently in the cell and

186 voltammograms were obtained at $10 \mathrm{~min}$ intervals for $60 \mathrm{~min}$. It should be noted that

187 protein solutions were stirred between measurements for 3 minutes; GC electrodes

188 were cleaned, polished, and tested with methyl viologen between each new MIP/NIP

189 experiment. Cyclic voltammograms using bare GC electrodes were also recorded for

190 the PBS (pH 7.4) and SDS 5\% (w/v) buffer solution and for the $15.4 \mu \mathrm{mol} \mathrm{L}^{-1}$ protein

191 solutions (BHb, BSA, EMb and Cyt C) dissolved in PBS buffer (pH 7.4) and SDS 5\% $192(\mathrm{w} / \mathrm{v})$.

193

\subsection{Principal component analysis}

Principal component analysis (PCA) and hierarchical cluster analysis (HCA)

196 were performed in Statistica 11.0 (StatSoft Inc., Tulsa, USA). The analysis was 
carried out using voltammetric current density values without any previously preprocessing and scaling from bare GC or modified GC electrodes as input. PCA was used to reduce the large data sets to $2 \mathrm{D}$ plots, which can be easily used to discriminate protein samples. All voltammetric curves were recorded three times for each sample

201 in a random order using a clean bare GC or a new modified GC electrode surface.

\section{Results and discussion}

\subsection{Characterisation}

Figure $1 \mathrm{~A}$ and $1 \mathrm{~B}$ show the optical microscope images of granulated and washed BHb MIPs and NIPs. The MIPs appear denser than the NIPs due to the light contrast apparent from protein which is still locked in the bulk of the MIP. It is also evident that the MIP particles form larger agglomerates with each other compared with the NIP. This is because there is still surface entrapped protein in the MIP particles which is attracted to more surface entrapped protein within other MIP

211 particles. This is not observed with the NIP. The molecular imprinting effect is characterised by the rebinding capacity (Q)

213 of protein to the gel polymer $(\mathrm{mg} / \mathrm{g}$ ) exhibited by the protein-specific MIP and the 214 control NIP, and is calculated using Eq. (1), where $C_{i}$ and $C_{r}$ are the initial protein and 215 the recovered protein concentrations $(\mathrm{mg} / \mathrm{ml}$ ) respectively (which specifies the 216 specific protein bound within the gel), $\mathrm{V}$ is the volume of the initial solution ( $\mathrm{ml}$ ), and $217 \mathrm{~g}$ is the mass of the gel polymers $(\mathrm{g})$.

$$
\mathrm{Q}=\left[\mathrm{C}_{\mathrm{i}}-\mathrm{C}_{\mathrm{r}}\right] \mathrm{V} / \mathrm{g}
$$

Figure 1C shows the rebinding capacities for each protein studied. As expected, the MIP exhibited superior selective binding of the target protein compared

221 with the NIP with a typical selectivity ratio of 10:1. Interestingly, the binding capacity 


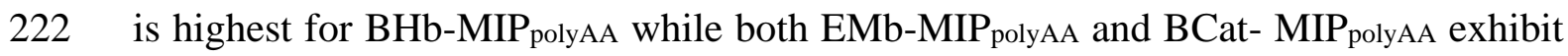

223 the lowest binding capacity. It has previously been observed that with smaller size

224 proteins a higher crosslinking density is necessary; the opposite is also true for larger

225 proteins [12,30]. Since the crosslinking density remained the same (10\% by weight),

226 the low MIP affinities for BCat and EMb can be attributed to the fact that fewer 227 cavities were imprinted due too high, and too low of a crosslinking density 228 respectively.

\section{$230 \quad 3.2$ Electrochemical analysis}

$231 \quad 3.2 .1$ Glassy carbon $(G C)$ profiling

Metallo-proteins are expected to produce an electrochemical signal because of 233 their metal-containing haem active centres in the protein molecules. However, the 234 extended three-dimensional structure of proteins results in the inaccessibility of the 235 electroactive iron centres. It can therefore be difficult for metallo-proteins to undergo 236 heterogeneous electron transfer; as a result, no detectable current appears at 237 conventional electrodes [1,4]. However, conformational changes due to partial or 238 complete protein denaturation, can allow haem groups to become accessible to a 239 subjacent electrode and be electrochemically reduced at GC electrodes via promotion 240 of electrocatalytic reduction of nascent oxygen [1]. For example, conformational or 241 structural changes in oxyhaemoglobin $(\mathrm{Hb})$ complexes can be induced upon 242 denaturation in the presence of sodium dodecylsulphate (SDS) denaturant $[1,11,31]$.

243 With this in mind, we attempted to evaluate the possibility to discriminate the 244 proteins using cyclic voltammetric information extracted from bare GC electrodes in 245 the presence of an SDS surfactant in solution. Cyclic voltammograms were recorded 246 in the presence of the four proteins that were studied at $15.4 \mu \mathrm{mol} \mathrm{L}^{-1}$ (including one 
non-metalloprotein as a control; $\mathrm{BHb}-1 \mathrm{mg} \mathrm{mL} \mathrm{L}^{-1}, \mathrm{BSA}-0.98 \mathrm{mg} \mathrm{mL} \mathrm{m}^{-1}, \mathrm{EMb}-0.26$ $\mathrm{mg} \mathrm{mL}^{-1}$, and Cyt $\mathrm{C}-0.185 \mathrm{mg} \mathrm{mL}^{-1}$ ) in a solution containing PBS buffer ( $\mathrm{pH} 7.4$ ) and $5 \%$ SDS (w/v) (Figure 2A). In the presence of Cyt C and BSA, the cathodic 250 reduction signal of dissolved oxygen in solution could be seen (reduction peak at -0.6 $251 \mathrm{~V})$. The fact that the peak was due to dissolved oxygen was confirmed by bubbling 252 Ar in the latter protein solutions, which consequently led to depletion of the oxygen 253 reduction peak (results not shown). In the presence of $\mathrm{BHb}$ and $\mathrm{EMb}$, a shift in the 254 peak reduction potential towards a less negative potential was observed, indicating an 255 iron centre-dependent electrocatalytic process for the oxygen reduction reaction at the 256 surface of the electrode. This effect was not observed in the absence of SDS, and is 257 therefore due to a probable SDS-induced change in the haemoglobin and myoglobin 258 structural conformation exposing the Fe(III) centre by partial denaturation. The 259 partial denaturation is induced only by SDS where at $5 \%(\mathrm{w} / \mathrm{v})$ the CMC is reached. 260 Full denaturation however, requires a combination of SDS surfactant and an acid in 261 order to protonate the protein and hence be further attracted to and unravelled by 262 negatively charged SDS micelles [31]. With this modification, the reduction of the 263 oxygen does not directly happen at the electrode surface; the Fe(III) is reduced to $264 \mathrm{Fe}(\mathrm{II})$ at the electrode surface and the oxygen reduction is subsequently 265 electrocatalysed by the oxidation of Fe(II) back to Fe(III).

266 Using hierarchical cluster analysis (HCA) the qualitative discrimination of the 267 proteins on the GC electrode was performed and data were analysed for their 268 discrimination and compiled as number of cluster recognition (Figure 2B). The results 269 reveal that a slight degree of separation between the proteins that, in solution, exhibit 270 and do not exhibit a shift in the peak reduction potential of the oxygen 271 electrochemical process, as clearly observed in the voltammetric profile. However, 
further evaluation of the recognized sample similarities shows that the model using

273 data extract with a bare electrode was unable to clearly discriminate individual

274 proteins inside the groups of protein clusters.

\subsubsection{Hydrogel profiling}

That the MIP can detect partially denatured protein is of significance to the exploitation of this electrochemical technique in protein discrimination. Indeed Kryscico et al. recently demonstrated using CD spectroscopy that during the 280 imprinting process, some of the protein undergoes conformational changes and is 281 partially denatured [32,33]. The MIPs therefore are imprinted with both native as well 282 as partially denatured protein. The MIPs and NIPs were therefore analysed 283 electrochemically with SDS treated protein to give partially denatured protein.

285 surface via diffusion should be delayed by the MIP due to attractive selective

286 interactions with exposed cavities [1]. With this in mind, GC electrode surfaces were 287 individually modified with a conditioned hydrogel layer (20 mg) of BHb MIP, EMb 288 MIP, Cyc C MIP, and BSA MIP.

289 To ensure the successful elution of protein from the MIP (and thus confirming 290 the presence of selective cavities through conditioning), BHb MIPs at different stages 291 were tested electrochemically on the electrode. Figure 3A characterizes the cyclic 292 voltammograms for freshly prepared MIP (with BHb still in the cavities; referred to as 293 MIP1), the same MIP washed to remove protein (referred to as MIP2) and also NIP. 294 The results clearly demonstrate that the MIP loaded with protein exhibits similar 295 electrochemistry to the BHb solution in Figure 2A. The reduction peak observed at 296 around $-0.4 \mathrm{~V}$ is the iron mediated reduction of oxygen. This suggests that the GC 
electrode is able to detect the protein at the surface due to the 'un-eluted' MIP's presence and concurred with previously reported electrochemical MIP studies [1].

299 Conversely, when protein is not present in either the MIP or the NIP, the 300 electrochemistry (reduction peak at $-0.6 \mathrm{~V}$ ) reverts to direct electrochemical reduction 301 of dissolved oxygen.

Protein diffusion through MIP and NIP layers was initially studied at 154 and 15.4 $\mu \mathrm{mol} \mathrm{L} \mathrm{L}^{-1}$. Whereas the NIP response time remained constant at $10 \mathrm{~min}$ for all protein concentrations, we found that the MIP response time decreases from our previously reported $40 \mathrm{~min}$ [1] to $10 \mathrm{~min}$ at low protein concentrations. Figure $3 \mathrm{~B}$ illustrates the resulting voltammograms for 0 and 10 minutes of BHb exposure at 15.4 $307 \mu \mathrm{mol} \mathrm{L} \mathrm{L}^{-1}$ using a modified BHb-MIP layer $(20 \mathrm{mg})$. It can be seen that a shift in the 308 peak reduction potential for the oxygen reduction was observed after only $10 \mathrm{~min}$ of $309 \mathrm{BHb}$ exposure. Therefore, both MIP and NIP share the same reduced response time at 310 lower concentrations. This result suggests that the template protein exhibits little 311 interaction with the MIP cavities at the lower concentrations, which is associated with 312 a less tortuous path to the electrode. It could be that at low protein concentrations we 313 observe extensive protein denaturation in the presence of SDS and therefore there is 314 little or no interaction between denatured protein and the mixed population of MIP 315 cavities for native and partially denatured protein.

316 Another possibility is that the 'template' forms a mixed population of free and 317 clustered proteins when the template is imprinted at a very high concentration (12 mg $318 \mathrm{~mL}^{-1}$ ). The resultant population of imprinted sites would therefore contain some 319 cavities that are associated with protein clusters. This phenomenon is supported by 320 our previous work [34,35], where force spectroscopy analysis of MIPs suggested that 321 the cavities accommodated an agglomeration of template protein molecules rather 
than just a single molecule. It is therefore possible that the solution phase represents a more dispersed protein population compared with the original imprinted template population for rebinding protein at low concentrations. If the cavities only respond to a critical number of protein molecules in a given arrangement, then this could explain why the MIP does not appear to be selective at low protein concentrations.

However, although the presence of SDS in solution $(5 \%(\mathrm{w} / \mathrm{v}))$ allows for protein detection at the electrode by iron exposure, it also implies that MIP recognition within the specific cavities may technically not be able to rebind the partially denatured and unfolded protein structures due to an altered size and shape. In light of this, recent studies have shown that when imprinting a mixture of stable and partially denatured proteins are present $[9,32,33]$. Therefore it is still possible that the MIPs can function as a recognition element and rebind a small percentage of the heterogeneous protein configurations.

In order to confirm these assumptions and elucidate the hypothesis that MIP cavities undergo an electrochemical discrimination of their template proteins, individually modified GC electrodes with all four hydrogel MIP layers were separately tested across all four proteins. Cyclic voltammograms for all MIP were recorded in a solution containing PBS (pH 7.4), SDS 5\% (w/v), and $15.4 \mu \mathrm{mol} \mathrm{L}^{-1}$ of the four proteins for different times of protein exposure (0-60 minutes). It was noted

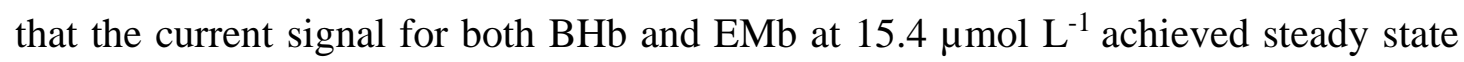
behaviour after 10 minutes, indicating that this time could be used for all further measurements. Therefore, using the voltammetric current density values PCA score plots for each MIP and protein combination were plotted at 10 minutes of protein exposure. 
Figure 4A illustrates the average PCA score plot for the four MIPs as they all

347 shared the same cluster separation. A clear discrimination and separation (using 92.9

$348 \%$ of the original information) of the four proteins clusters at $10 \mathrm{~min}$ of protein

349 exposure can be seen. This indicated that MIP cavity interactions could play an

350 important role in the discrimination process. Of the four different clusters, Cyt $\mathrm{C}$ and

351 BSA clusters are far less scattered than $\mathrm{BHb}$ and EMb clusters. An explanation for 352 this behaviour could be ascribed to the fact that the BHb MIP was selective for both $353 \mathrm{BHb}$ and $\mathrm{EMb}$ (which bear similarities in their structure), allowing for them to bind in 354 the MIP cavities and consequently making the diffusion rate less reproducible in the 355 MIP. The separation for Cyt C and BSA can be justified due to their adsorption at GC 356 electrode surfaces, subsequently changing the rate of the oxygen reduction. A change 357 in the peak current and in the current decay from peak current to $-0.8 \mathrm{~V}$ ( $\Delta \mathrm{I}_{\text {decay }}$ peak 358 current to $-0.8 \mathrm{v}$ ) for the oxygen reduction was observed for all the experiments with Cyt C 359 and BSA proteins when compared with a blank solution. These adsorption rates of 360 Cyt C and BSA can be related to previously published values [27,36]. It is plausible 361 that this adsorption effect and delayed diffusion due to MIP cavity interactions are 362 responsible for the discrimination process [37]. PCA loading plots revealed the 363 variables responsible for the separation of the proteins; 5 variables could be elected:

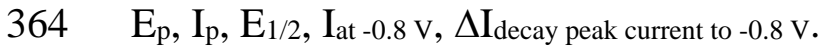

365 Thus, the effective diffusion rate of proteins through the composite 366 membranes could be a function of specific and non-specific cavities of the polymeric 367 MIP layer [37]. Therefore, the time of protein diffusion was considered an important 368 parameter for the discrimination process. This indicated that GC electrodes modified 369 with an acrylamide cavity-based MIP could be used as a sensor to discriminate 370 different kinds of proteins at 10 minutes of protein exposure. However, mechanical 
obstruction of the polymeric layer using a control non-imprinted polymer (NIP) on the

372 GC electrode surface was conducted in order to validate the MIP-protein rebinding 373 profiles. This allows only for the non-specificity of the polymeric layer to be 374 evaluated due to the lack of selective cavities. All discrimination experiments were 375 executed identically as reported using the MIP layers; the only altered variable was 376 the modified NIP layer (20 mg). Unfortunately, PCA plots revealed NIP to have 377 similar protein discrimination (Figure 4B) to that of a MIP at 10 minutes of protein 378 exposure. Therefore only the protein diffusion rate through the polymeric layer could 379 be considered as a possible discriminating factor for the four proteins.

380 A closer look at the PCA data using interpreted HCA data compiled as number 381 of cluster recognition reveals that the four proteins are best profiled using both MIP 382 and NIP layers (Figure 5A and B, respectively) when compared with bare GC 383 electrode (Figure 2B). The symmetric measures between our protein discrimination 384 models, in terms of a percentage measurement of agreement using Cohen's kappa 385 coefficient $(\kappa)$, are illustrated in Table 1 . Since the approx. significance $(p)=.000$ 386 (which actually means $p<.0005$ ), our $\kappa$ coefficients are statistically significantly 387 different from zero (63\% for bare GC, $96 \%$ for NIP and 100\% for MIP). Therefore, 388 there is a clear comparison between the behavioural models for protein 389 discrimination.

390 Furthermore, clustering relationships for each of the four proteins are 391 apparent; this phenomenon is especially noticeable in the MIP and NIP PCA plots 392 (Figure 4). It should be noted that in different studies, involving bare GC electrodes, 393 MIP modified GC electrodes or NIP modified GC electrodes, all PCA protein clusters 394 fall into the same pattern recognition, thus providing an overall cohesive protein 395 profile. Each protein retains its own individual cluster within a single quadrant of the 
396 PCA plot. Interestingly, our studies illustrate that proteins with a metal center behave 397 similarly; it can clearly be seen that both metalloproteins that exhibit a peak potential 398 shift (BHb and $\mathrm{EMb})$ are on the right half of the vector, while BSA and Cyt $\mathrm{C}$ are on 399 the other. Moreover, the smaller sized proteins (EMB $\sim 17.5 \mathrm{kDa}$ and $\mathrm{Cyt} \mathrm{C} \sim 12.5 \mathrm{kDa}$ ) 400 are on the top half of the plot. This recognition approach could be useful for future 401 protein speciation profiling.

\section{Conclusions}

The proposed electrochemical and PCA coupled method proved to be efficient

405 for discriminating four proteins $(\mathrm{BHb}, \mathrm{Mb}, \mathrm{BSA}$ and $\mathrm{Cyt} \mathrm{C})$, indicating that glassy 406 carbon (GC) electrodes modified with either a MIP or NIP layer could be used as a 407 fast sensor to discriminate between different kinds of proteins. At high concentrations, 408 the selective nature and integrity of MIPs delays the protein response and leads to an 409 obvious difference between MIP and NIP performance. At lower concentrations, such 410 discriminations are difficult due to an apparent lack of critical protein agglomeration 411 and/or complete denaturation of protein molecules impeding optimum protein binding 412 within cavities. With the use of PCA, protein discrimination has been achievable at 413 faster detection rates. Our results suggest that PCA could be used to interrogate and 414 discriminate between proteins when hydrogels are integrated to electrochemical 415 sensors.

\section{Acknowledgements}

418 The authors are grateful to the University Global Partnership Network 419 (Universities of Surrey, Sao Paulo and NC State), The Royal Society, NERC, ACTF 420 of the RSC, FAPESP (Fundação de Amparo à Pesquisa do Estado de São Paulo; 
421 Grant Numbers: 2012/12106-5, 2011/11115-8, 2011/23355-3), CAPES (Coordenação 422 de Aperfeiçoamento de Pessoal de Nível Superior), and CNPq (Conselho Nacional de 423 Desenvolvimento Científico e Tecnológico; Grant Numbers: 470919/2011-6 and 424 302700/2011-0) for financial support.

425 The authors would also like to thank Dr PJ McCabe (Clinical Res Centre) at 426 the University of Surrey for his contributions towards the statistical evaluation of this 427 work.

428 


\section{References}

430 [1] S.M. Reddy, G. Sette, Q. Phan, Electrochemical probing of selective haemoglobin

431 binding in hydrogel-based molecularly imprinted polymers, Electrochim. Acta. 56

432 (2011) 9203-9208.

433 [2] H. Chen, Z. Zhang, R. Cai, X. Chen, Y. Liu, W. Rao, S. Yao, Molecularly

434 imprinted electrochemical sensor based on amine group modified graphene covalently

435 linked electrode for 4-nonylphenol detection, Talanta. 115 (2013) 222-227.

436 [3] B. Khadro, C. Sanglar, A. Bonhomme, A. Errachid, N. Jaffrezic-Renault,

437 Molecularly imprinted polymers (MIP) based electrochemical sensor for detection of

438 urea and creatinine, Procedia Engineering. 5 (2010) 371-374.

439 [4] X. Kan, Z. Xing, A. Zhu, Z. Zhao, G. Xu, C. Li, H. Zhou, Molecularly imprinted

440 polymers based electrochemical sensor for bovine hemoglobin recognition, Sensors

441 Actuators B: Chem. 168 (2012) 395-401.

442 [5] S.A. Piletsky, N.W. Turner, P. Laitenberger, Molecularly imprinted polymers in

443 clinical diagnostics-Future potential and existing problems, Med. Eng. Phys. 28

444 (2006) 971-977.

445 [6] V.J.B. Ruigrok, M. Levisson, M.H.M. Eppink, H. Smidt, J. van der Oost,

446 Alternative affinity tools: more attractive than antibodies? Biochem. J. 436 (2011) 1-

44713.

448 [7] M.E. Byrne, V. Salian, Molecular imprinting within hydrogels II: Progress and 449 analysis of the field, Int. J. Pharm. 364 (2008) 188-212. 
451 to Biotech Application: Selectivity and Ruggedness, Procedia Engineering. 47 (2012) $452 \quad 534-537$.

453 [9] D.R. Kryscio, N.A. Peppas, Critical review and perspective of macromolecularly 454 imprinted polymers, Acta Biomaterialia. 8 (2012) 461-473.

455 [10] S.M. Reddy, D.M. Hawkins, Q.T. Phan, D. Stevenson, K. Warriner, Protein 456 detection using hydrogel-based molecularly imprinted polymers integrated with dual 457 polarisation interferometry, Sensors Actuators B: Chem. 176 (2013) 190-197.

458 [11] E. Verheyen, J.P. Schillemans, M. van Wijk, M. Demeniex, W.E. Hennink, C.F. 459 van Nostrum, Challenges for the effective molecular imprinting of proteins, 460 Biomaterials. 32 (2011) 3008-3020.

461 [12] H.F. El-Sharif, Q.T. Phan, S.M. Reddy, Enhanced selectivity of hydrogel-based 462 molecularly imprinted polymers (HydroMIPs) following buffer conditioning, Anal. 463 Chim. Acta. 809 (2014) 155-161.

464 [13] H.C. Zhou, L. Baldini, J. Hong, A.J. Wilson, A.D. Hamilton, Pattern recognition 465 of proteins based on an array of functionalized porphyrins, J. Am. Chem. Soc. 128 466 (2006) 2421-2425.

467 [14] Y. Vlasov, A. Legin, A. Rudnitskaya, C. Di Natale, A. D'Amico, Nonspecific 468 sensor arrays ("electronic tongue") for chemical analysis of liquids (IUPAC Technical 469 Report), Pure and Applied Chemistry. 77 (2005) 1965-1983.

470 [15] K. Toko, Taste sensor with global selectivity, Materials Science \& Engineering 471 C-Biomimetic Materials Sensors and Systems. 4 (1996) 69-82. 
[16] J. Zeravik, A. Hlavacek, K. Lacina, P. Skládal, State of the Art in the Field of Electronic and Bioelectronic Tongues? Towards the Analysis of Wines, Electroanalysis. 21 (2009) 2509-2520.

[17] E.A. Baldwin, J. Bai, A. Plotto, S. Dea, Electronic Noses and Tongues: Applications for the Food and Pharmaceutical Industries, Sensors. 11 (2011) 47444766.

[18] C. Baggiani, L. Anfossi, C. Giovannoli, C. Tozzi, Multivariate analysis of the selectivity for a pentachlorophenol-imprinted polymer, Journal of Chromatography B. 804 (2004) 31-41.

[19] T. Takeuchi, D. Goto, H. Shinmori, Protein profiling by protein imprinted polymer array, Analyst. 132 (2007) 101-103.

[20] T. Takeuchi, T. Hishiya, Molecular imprinting of proteins emerging as a tool for protein recognition, Organic \& Biomolecular Chemistry. 6 (2008) 2459.

[21] K.D. Shimizu, C.J. Stephenson, Molecularly imprinted polymer sensor arrays, Curr. Opin. Chem. Biol. 14 (2010) 743-750.

[22] T.R.L.C. Paixao, M. Bertotti, Fabrication of disposable voltammetric electronic tongues by using Prussian Blue films electrodeposited onto CD-R gold surfaces and recognition of milk adulteration, Sensors and Actuators B-Chemical. 137 (2009) 266273.

[23] M.O. Salles, M. Bertotti, T.R.L.C. Paixao, Use of a gold microelectrode for discrimination of gunshot residues, Sensors and Actuators B-Chemical. 166 (2012) $848-852$. 
494 [24] W. Novakowski, M. Bertotti, T.R.L.C. Paixao, Use of copper and gold electrodes 495 as sensitive elements for fabrication of an electronic tongue: Discrimination of wines 496 and whiskies, Microchemical Journal. 99 (2011) 145-151.

497 [25] L. Bueno, R.L.C. Paixão Thiago, A Single Platinum Microelectrode for 498 Identifying Soft Drink Samples, International Journal of Electrochemistry. 2012 499 (2012) 1-5.

500 [26] Q. Gai, F. Qu, Y. Zhang, The Preparation of BHb-Molecularly Imprinted Gel 501 Polymers and Its Selectivity Comparison to BHb and BSA, Sep. Sci. Technol. 45 502 (2010) 2394-2399.

503 [27] S. Boussaad, N.J. Tao, R. Zhang, T. Hopson, L.A. Nagahara, In situ detection of 504 cytochrome c adsorption with single walled carbon nanotube device, Chem. Commun. $505 \quad 0(2003) 1502-1503$.

506 [28] S. Wu, W. Tan, H. Xu, Protein molecularly imprinted polyacrylamide membrane: 507 for hemoglobin sensing, Analyst. 135 (2010) 2523-2527.

508 [29] M.J. Whitcombe, I. Chianella, L. Larcombe, S.A. Piletsky, J. Noble, R. Porter, A. 509 Horgan, The rational development of molecularly imprinted polymer-based sensors 510 for protein detection, Chem. Soc. Rev. 40 (2011) 1547-1571.

511 [30] D.E. Hansen, Recent developments in the molecular imprinting of proteins, 512 Biomaterials. 28 (2007) 4178-4191.

513 [31] D.M. Hawkins, D. Stevenson, S.M. Reddy, Investigation of protein imprinting in 514 hydrogel-based molecularly imprinted polymers (HydroMIPs), Anal. Chim. Acta. 542 $515 \quad$ (2005) 61-65. 
516 [32] D.R. Kryscio, M.Q. Fleming, N.A. Peppas, Conformational studies of common

517 protein templates in macromolecularly imprinted polymers, Biomed. Microdevices.

51814 (2012) 679-687.

519 [33] D.R. Kryscio, M.Q. Fleming, N.A. Peppas, Protein Conformational Studies for

520 Macromolecularly Imprinted Polymers, Macromolecular Bioscience. 12 (2012) 1137-

5211144.

522 [34] E. Saridakis, S. Khurshid, L. Govada, Q. Phan, D. Hawkins, G.V. Crichlow, E.

523 Lolis, S.M. Reddy, N.E. Chayen, Protein crystallization facilitated by molecularly

524 imprinted polymers, Proceedings of the National Academy of Sciences. 108 (2011)

525 11081-11086.

526 [35] H. EL-Sharif, D.M. Hawkins, D. Stevenson, S.M. Reddy, Determination of

527 protein binding affinities within hydrogel-based molecularly imprinted polymers

528 (HydroMIPs), Phys. Chem. Chem. Phys. 16 (2014) 15483-15489.

529 [36] X. Zhao, R. Liu, Z. Chi, Y. Teng, P. Qin, New Insights into the Behavior of

530 Bovine Serum Albumin Adsorbed onto Carbon Nanotubes: Comprehensive

531 Spectroscopic Studies, J Phys Chem B. 114 (2010) 5625-5631.

532 [37] R. Schirhagl, U. Latif, D. Podlipna, H. Blumenstock, F.L. Dickert, Natural and

533 Biomimetic Materials for the Detection of Insulin, Anal. Chem. 84 (2012) 3908-3913. 
538 Table 1 - Symmetric Measures; Cohen's kappa coefficient $(\kappa)$ as a percentage 539 measurement of agreement, asymptotic std. error not assuming the null hypothesis ${ }^{\mathrm{a}}$, 540 approximate $\mathrm{T}$ as the ratio of $\kappa$ to the asymptotic standard error assuming the null 541 hypothesis $^{\mathrm{b}}$, and the approximate statistical significance (p).

542

543 


\section{Figure captions}

546 Figure 1 - Microscope imaging of $75 \mu \mathrm{m}$ hydrogel particles: (A) non-imprinted control

547 (NIP); (B) bovine haemoglobin (BHb) imprinted MIP polyAA. (C) Rebinding capacities 548 and imprinting effects of $\mathrm{MIP}_{\text {polyAA }}$ and $\mathrm{NIP}_{\text {polyAA }}$ for several biological molecules

549 (bovine haemoglobin (BHb), bovine serum albumin (BSA), myoglobin (Mb), 550 Cytochrom C (Cyt C)). Data represents mean \pm S.E.M., $n=3$.

552 Figure 2 - (A) Cyclic voltammograms recorded in PBS (pH 7.4), SDS 5\% (w/v), and 553 in the presence of protein in solution $\left(15.4 \mu \mathrm{mol} \mathrm{L}^{-1}\right)$ (cytochrome $\mathrm{C}$ (a), bovine serum 554 albumin (b), equine heart myoglobin (c) and bovine haemoglobin (d)). Scan rate: 100 $555 \mathrm{mV} \mathrm{s}^{-1}$. Electrode: bare glassy carbon (GC) electrode. (B) Cluster analysis percentage 556 prediction scores for the four proteins using GC electrodes.

558 Figure 3 - Cyclic voltammograms recorded in PBS (pH 7.4), SDS 5\% (w/v), and in 559 the presence of $\mathrm{BHb}$ in solution $\left(15.4 \mu \mathrm{mol} \mathrm{L}^{-1}\right)$ at scan rate of $100 \mathrm{mV} \mathrm{s}^{-1}$ : (A) Glassy 560 carbon (GC) electrode modified with hydrogel layers of NIP (a), unconditioned BHb561 MIP1 (b), conditioned BHb-MIP2 (c) after 0 minutes of protein exposure. (B) Glassy 562 carbon (GC) electrode modified with hydrogel layer of BHb MIP. Measurement made 563 after 0 (a) and 10 (b) minutes of protein exposure.

566 Figure 4 - PCA score plots: (A) glassy carbon (GC) electrode modified with hydrogel 567 MIP layer, results show the average response of all four different MIPs; (B) glassy 568 carbon (GC) electrode modified with a non-imprinted hydrogel layer. Voltammetric 
569 date recorded in PBS ( $\mathrm{pH} 7.4)$, SDS 5\% (w/v), and in the presence of each protein $570\left(15.4 \mu \mathrm{mol} \mathrm{L}^{-1}\right)$. Potential programme employed to record the voltammetric curves 571 used as input to perform PCA: $\mathrm{E}_{\mathrm{i}}=0.0 \mathrm{~V}, \mathrm{Ev}_{1}=-0.9 \mathrm{~V}, \mathrm{E}_{\mathrm{f}}=0.0 \mathrm{~V}$, and scan rate $=100$ $572 \mathrm{mV} \mathrm{s}^{-1}$. Measurement made after 10 minutes of protein exposure.

573

574 Figure 5 - Cluster analysis percentage prediction scores for the four proteins; (A) MIP 575 modified GC electrodes, (B) NIP modified GC electrodes.

576 
Table 1

\begin{tabular}{|c|c|c|c|c|}
\hline Model & $\mathbf{K}(\%)$ & Asymp. Std. Error $^{\mathbf{a}}$ & Approx. T $^{\text {b }}$ & Approx. Sig. ( $\boldsymbol{\rho})$ \\
\hline Bare GCE & $63 \%$ & 0.1 & 6.543 & 0.00 \\
NIP & $96 \%$ & 0.036 & 10.018 & 0.00 \\
Mb MIP & $100 \%$ & 0 & 10.392 & 0.00 \\
Cyt C MIP & $100 \%$ & 0 & 10.392 & 0.00 \\
BSA MIP & $100 \%$ & 0 & 10.392 & 0.00 \\
BHb MIP & $96 \%$ & 0.04 & 9.414 & 0.00 \\
\hline
\end{tabular}

578

579 

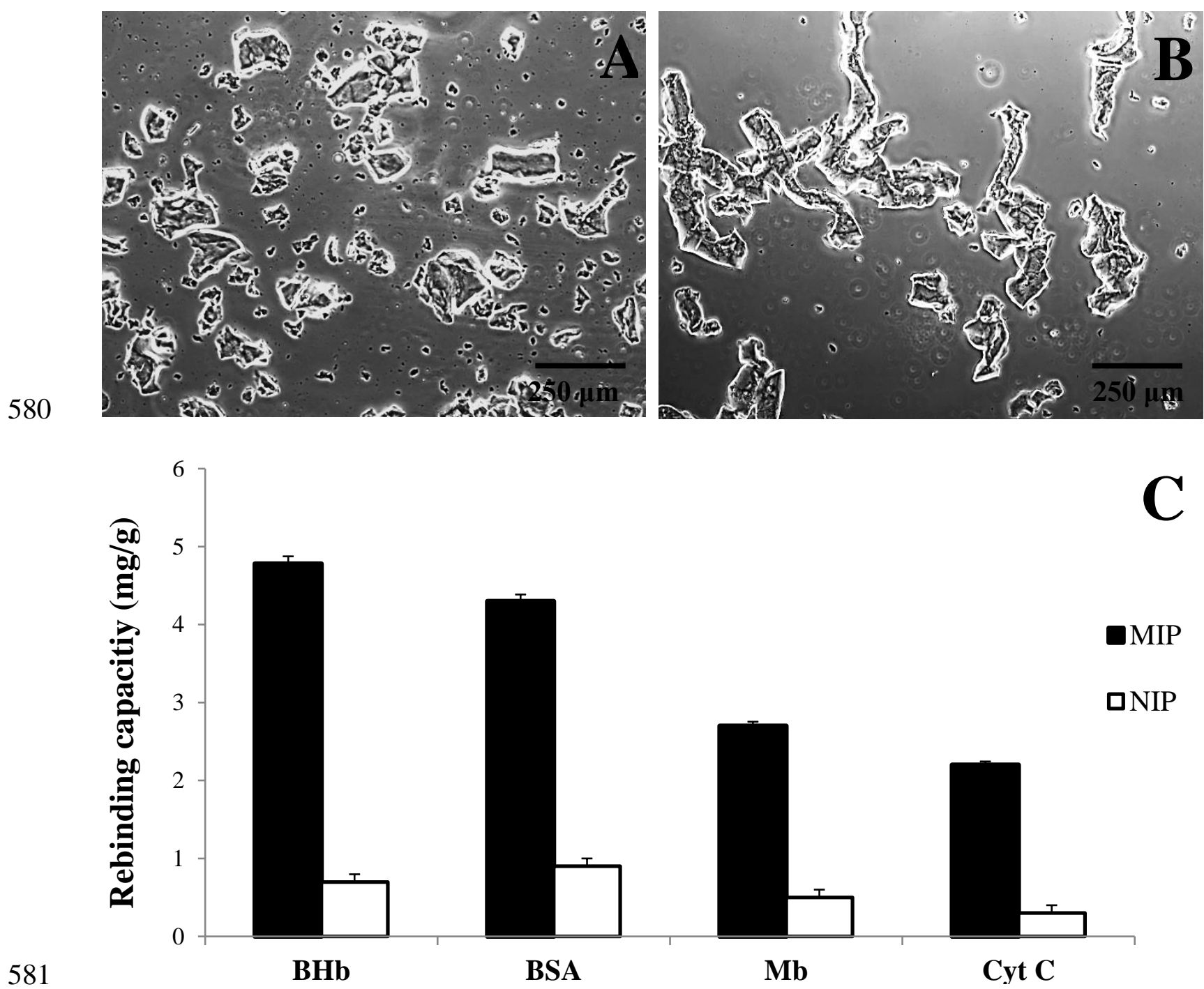

$582 \quad$ Figure 1 


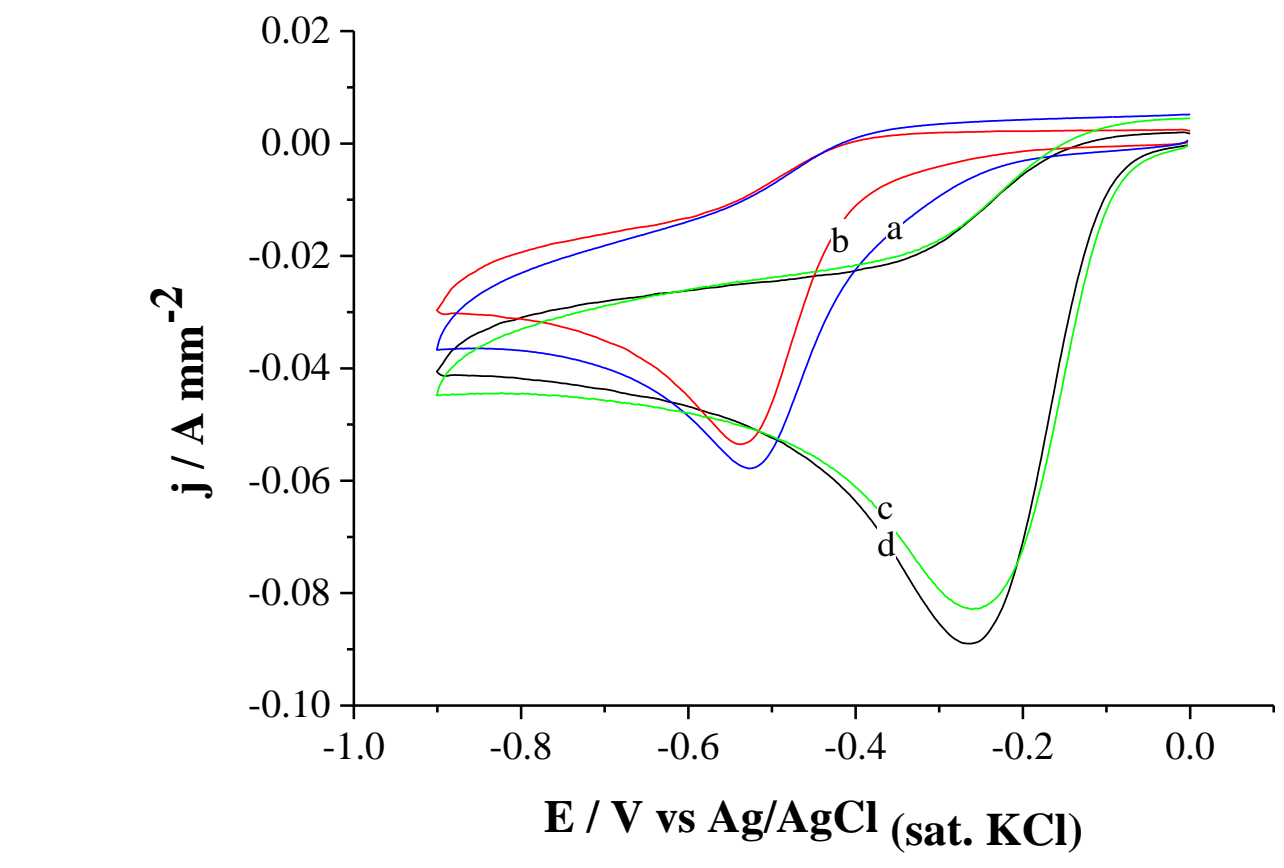

A

584

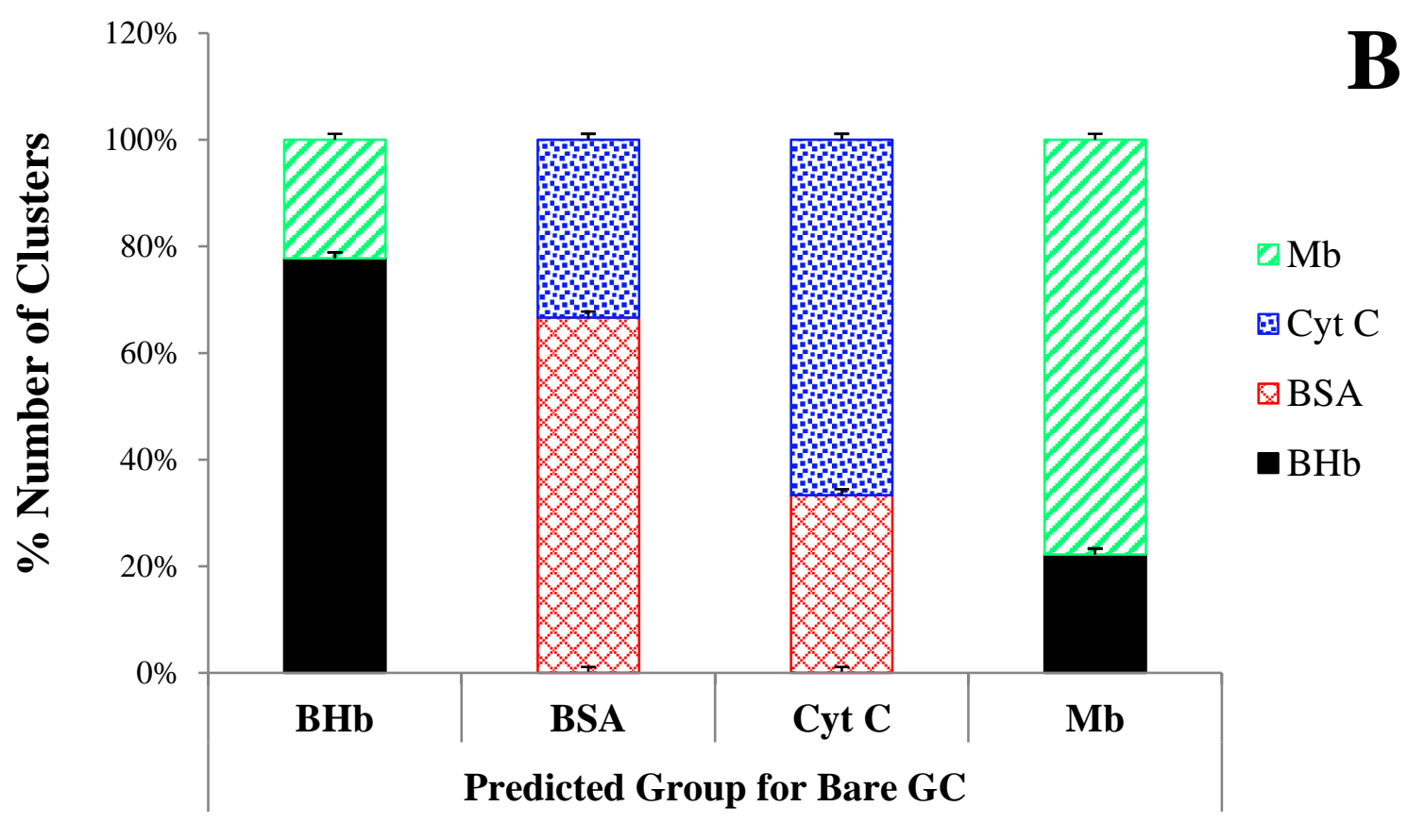

Figure 2 


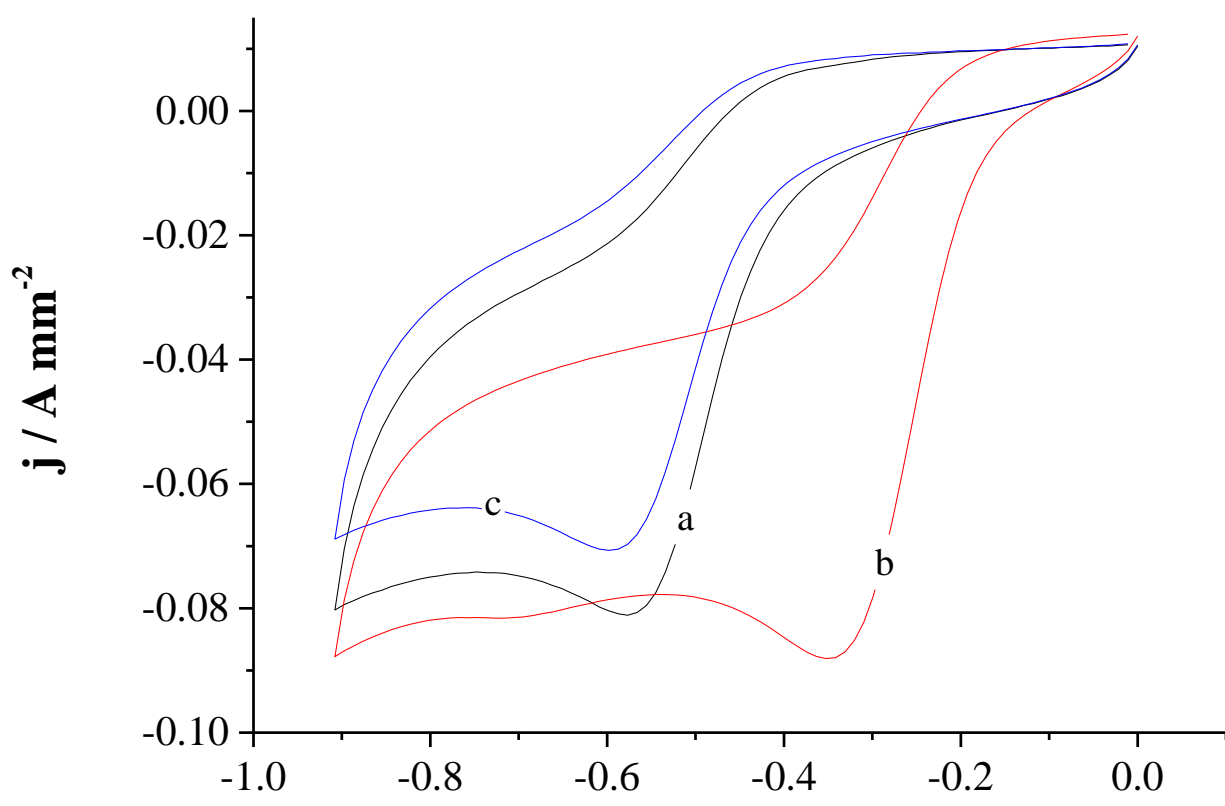

A

E / V vs Ag/AgCl (sat. KCl)

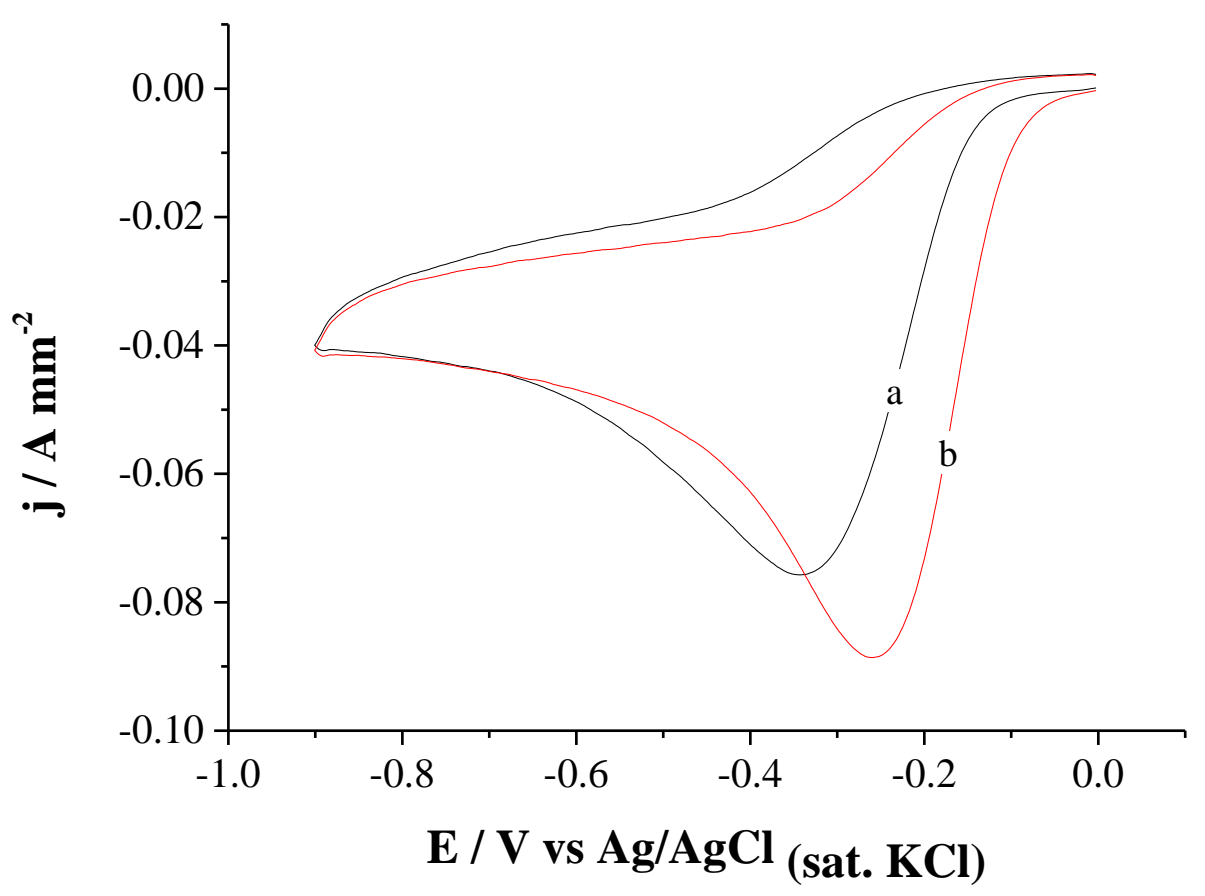

Figure 3 


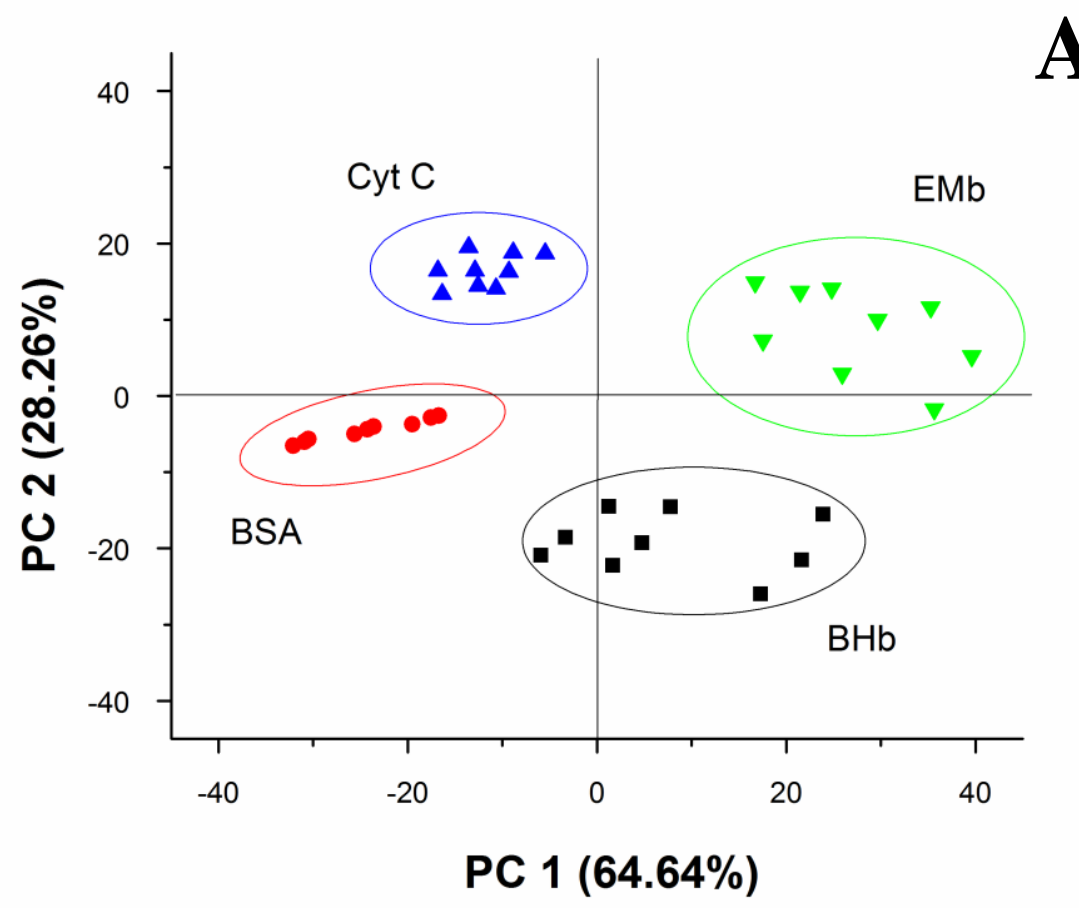

590

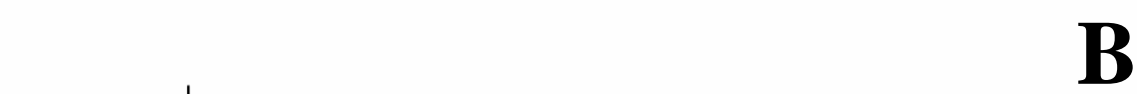

591

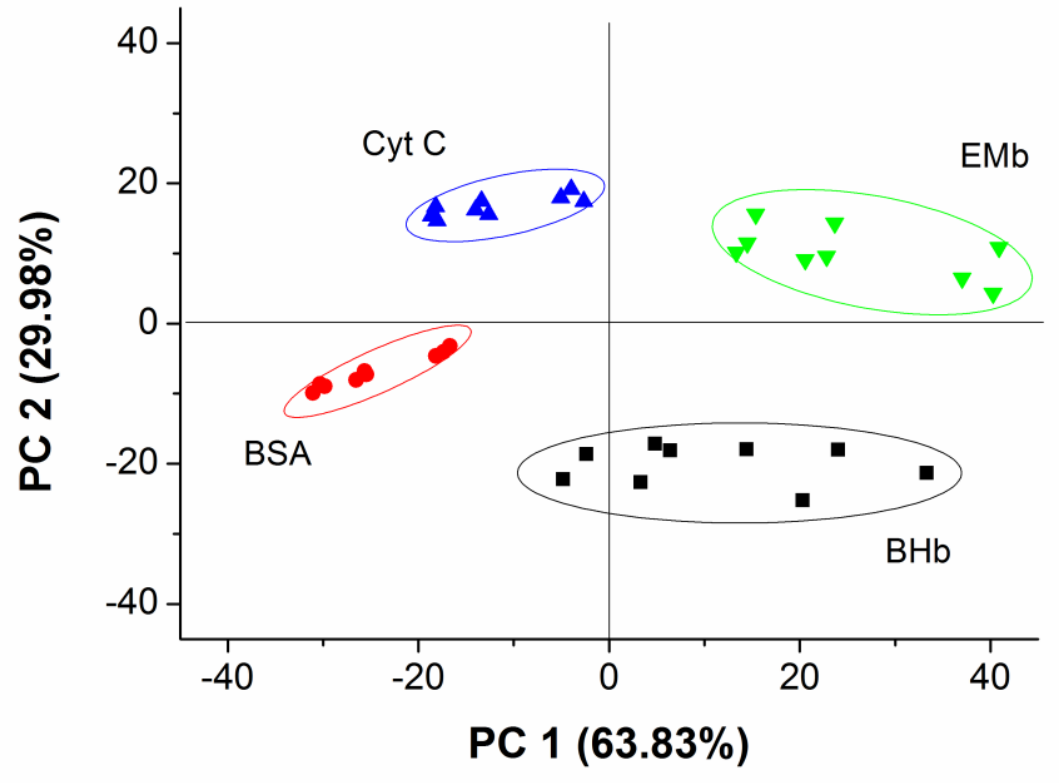

$592 \quad$ Figure 4

593 

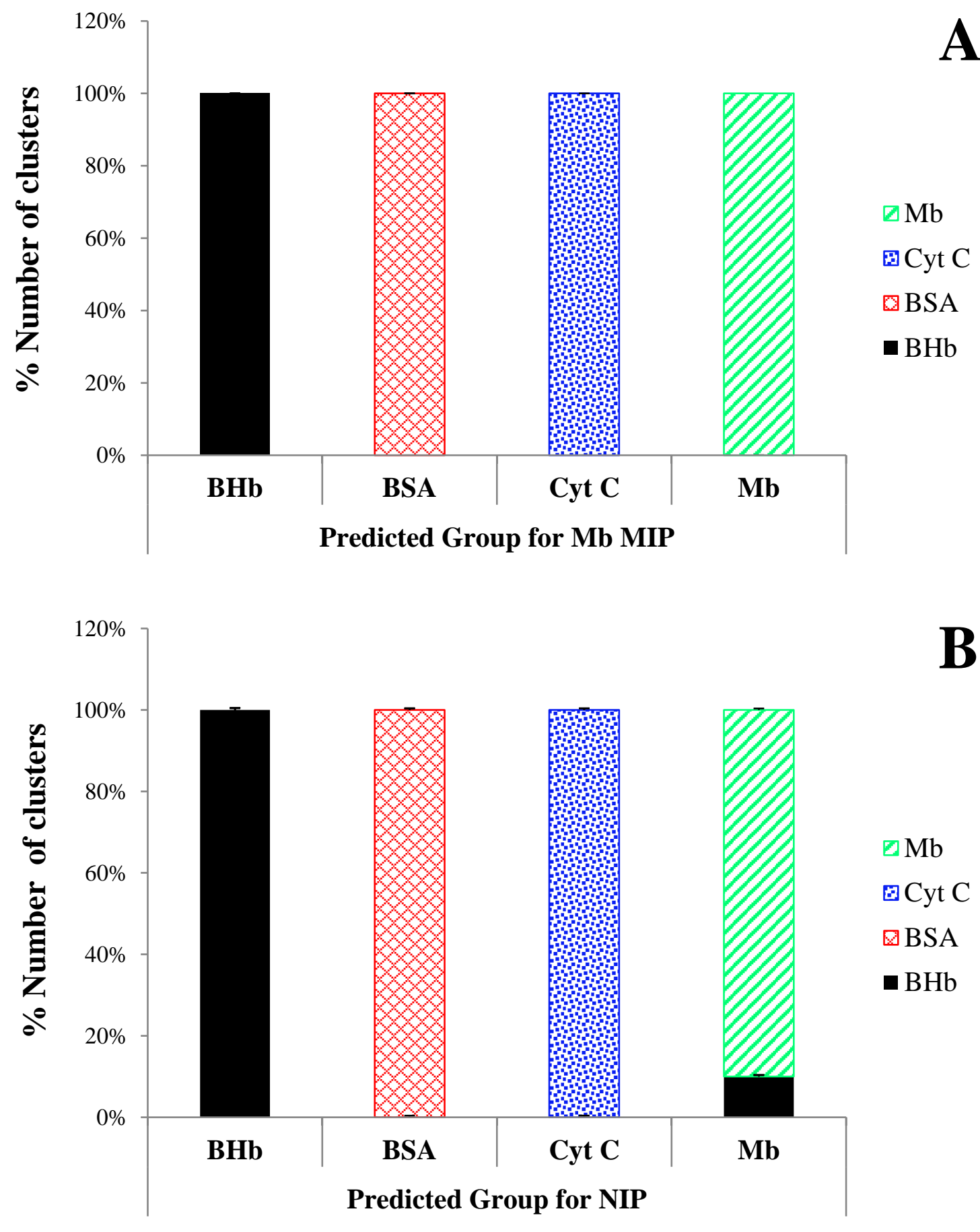

$597 \quad$ Figure 5 